\title{
KETIDAKSADARAN KOLEKTIF TOKOH DALAM NOVEL ANAK RANTAUKARYA AHMAD FUADI: KAJIAN PSIOKOLOGI ANALITIS CARLGUSTAV JUNG
}

\author{
Riskal Ahmad \\ Kantor Bahasa Maluku Utara \\ Jalan Raya Pertamina, Kelurahan Jambula, Kota Ternate \\ Pos-el: riskalahmad9@gmail.com
}

\begin{abstract}
Abstrak
Karya sastra berkait erat dengan kehidupan manusia sehari-hari dan merupakan pemikiran atau pengekspresian dari pengarang. Karya sastra sebagai ungkapan pribadi pengarang merupakan pengalaman, pikiran, perasaan, dan ide yang dituangkan dengan menggunakan bahasa sebagai mediumnya. Penelitian ini bertujuan menganalisis ketidaksadaran kolektif pada tokoh dalam novel Anak Rantau karya Ahmad Fuadi melalui pendekatan Psikoanalitis Carl Gustav Jung. Penelitian ini merupakan jenis penelitian kepustakaan. Data penelitian ini berupa novel yang berjudul Anak Rantau karya Ahmad Fuadi. Metode yang digunakan dalam penelitian ini adalah metode deskriptif kualitatif. Dari hasil penelitian ditemukan : (1) peranan persona dari diri seorang Datuk Marajo yang menampilkan satu karakter yang berbeda untuk menutupi karakter yang merupakan miliknya, (2) peranan arketipe anima dalam diri tokoh Martiaz yakni sisi feminin yang ada dalam diri seorang pria, (3) peranan bayang (shadow) pada tokoh Jenggo untuk menutupi kesalahannya, dan (4) peranan arketipe diri (self) pada Datuk Marajo untuk mendapatkan ketenangan.
\end{abstract}

Kata Kunci: psikoanalitis, ketidaksadaran kolektif, novel, anak rantau

\section{The Collective Awareness of Characters in the Children's Novel of Ahmad Fuadi's Works: Psiokoanalitic Study Carl Gustav Jung}

\begin{abstract}
Literary works are closely related to everyday human life and are the thoughts or expressions of the author. Literary works as the author's expression represent experiences, thoughts, feelings, and ideas expressed by using language as the medium. This study aims to analyze the collective unconsciousness of the characters in Ahmad Fuadi's novel Anak Rantau through the psychoanalytic approach of Carl Gustav Jung. This research is a type of library research. The research data is in the form of a novel entitled Anak Rantau by Ahmad Fuadi. The method used in this research is a descriptive qualitative method. From the results of the study, it was found: (1) the personal role of Datuk Marajo, which displays a different character to cover the character that belongs to him, (2) the role of the archetype of anima in Martiaz, namely the feminine side of a man, (3) ) the role of shadow (shadow) in the character Jenggo to cover his mistakes, and (4) the role of self-archetype (self) in Datuk Marajo to get calm.
\end{abstract}

Keywords: psychoanalytic, the collective unconscious, novel, Anak Rantau

\section{PENDAHULUAN}

Sastra mengacu pada dua pengertian yaitu sastra sebagai karya sastra dan sastra sebagai cabang ilmu pengetahuan. Definisi sastra yang digunakan dalam kerangka karya sastra yaitu hasil karya seni yang diciptakan pengarang atau kelompok masyarakat tertentu bermediakan bahasa serta dipandang 
sebagai sesuatu yang imajinatif (Wiyatmi, 2011).

Carl Gustav Jung merupakan salah satu pakar psikoanalisis yang membahas mengenai kepribadian. Menurut Jung, kepribadian tersimpan dalam wilayah kesadaran dan ketidaksadaran, kepribadian yang dimiliki seseorang dipengaruhi oleh pengalaman. Carl Gustav Jung membagi teorinya menjadi dua bagian yaitu kesadaran dan ketidaksadaran (Ismail, 1999)..

Kesadaran mempunyai dua hal penting yaitu fungsi jiwa dan sikap jiwa, sedangkan ketidaksadaran juga dibagi ke dalam dua bagian yaitu ketidaksadaran personal dan ketidaksadaran kolektif (Mutmainna, 2016).

Ketidaksadaran kolektif merupakan ingatan masa lalu yang diwariskan pendahulunya atau nenek moyang atau yang sering juga disebut dengan arketipe. Berbeda dengan ketidaksadaran personal, ketidaksadaran kolektif melalui proses yang panjang dari generasi ke generasi.

\section{Struktur Kepribadian Carl Gustav Jung}

Kepribadian berasal dari bahasa Inggris yaitu personality. Kepribadian yang hadir pada setiap tokoh utama merupakan bentuk gejolak diri seseorang. Adapun gejolak diri tersebut berhubungan dengan proses kesadaran dan ketidaksadaran dalam diri manusia (Sembiring et al., 2018).

Kepribadian menurut psikologi bisa mengacu pada pola karakteristik perilaku dan pola pikir yang menentukan penilaian seseorang terhadap lingkungan. Kepribadian dibentuk oleh potensi sejak lahir dan dimodifikasi oleh pengalaman budaya dan pengalaman unik yang memengaruhi seseorang sebagai individu. Dalam teori Psikoanalisis Jung, ketidaksadaran dibagi menjadi dua yaitu ketidaksadaran pribadi dan ketidaksadaran kolektif (Ismail, 1999).

\section{Ketaksadaran Pribadi}

Ketidaksadaran pribadi merupakan area yang letaknya berdekatan dengan ego dan terdiri ataspengalaman-pengalaman yang pernah sadar, tetapi kemudian direpresikan, disupresikan, dilupakan atau diabaikan serta pengalamanpengalaman yang terlalu lemah untuk menciptakan kesan sadar pada sang pribadi(Supratiknya, 1993).

Sebagai contoh, sebuah pengalaman yang dialami oleh individu pada awal masa kanak-kanak sedikit banyaknya akan selalu diingat hingga individu tersebut tumbuh dewasa.

\section{Ketaksadaran Kolektif}

Konsep ketidaksadaran kolektif menurut Carl Gustav Jung berisikan sistem psikis yang paling kuat dan yang paling berpengaruh hingga mengungguli ego dan ketidaksadaran pribadi.

Berdasarkan konsep Jung, isi fisik yang menyertai kesadaran kolektif diturunkan dari satu generasi ke generasi berikutnya sebagai sebuah kondisi psikis yang potensial. Orang berada dalam suatu kondisi dan waktu yang dipengaruhi oleh pengalaman primordial primitif nenek moyangnya.

Teori iniberasumsi bahwa fenomena yang berhubungan dengan kekuatan gaib atau magis (occult)bisa dan memang berpengaruh pada kehidupan semua manusia. Jung percaya bahwa setiap dari kita termotivasi bukan hanya oleh pengalaman yangditekan, melainkan oleh pengalaman emosional tertentu yang dipengaruhi olehpara leluhur (Qudwah, 2016)

Alam bawah sadar kolektif tidak merujuk pada ide yang diturunkan. Akan tetapi lebih kepada kecenderungan kuat manusia untuk beraksi dengan cara tertentu pada saat pengalaman mereka 
Riskal Ahmad: Ketidaksadaran Kolektif Tokoh dalam Novel Anak Rantau Karya Ahmad Fuadi (Kajian Psiokologi Analitis Carlgustav Jung)

menstimulasikan kecenderungan turunan secara biologis.

Manusia seperti halnya dengan hewan, datang ke dunia ini dengan sifat turunan yang telah ditentukan sebelumnya untuk dapat bereaksi dengan cara tertentu jika pengalamannya menyentuh sisi biologisnya. Jung mengatakan bahwa ketidaksadaran kolektif laki-laki yang mengandung impresi-impresi biologis pada seorang wanita berperan ketika laki-laki melihat wanita yang dicintainya.

Konsep ketaksadaran kolektif atau transpersonal merupakan salah satu di antara segi-segi teori kepribadian Jung yang paling original dan kontroversial. Merupakan sistem yang paling kuat dan paling berpengaruh, dan pada kasuskasus patologi ia mengungguli ketidaksadaran pribadi. Ketaksadaran kolektif merupakan bagian ketidaksadaran pribadi.

Ketaksadaran kolektif merupakan fondasi ras yang diwariskan keseluruhan struktur kepribadian. Semua yang dipelajari dari pengalaman secara substansial dipengaruhi oleh ketaksadaran kolektif yang menyeleksi dan mengarahkan tingkah laku sejak bayi. Bentuk dunia yang diciptakan akan dihadirkan dan gambaran-gambaran yang ada di dalamnya akan memengaruhi pilihan-pilihanpengalaman secara tidak sadar.

Ketidaksadaran kolektif merupakan kumpulan ingatan yang diwariskan oleh para leluhur, baik dalam wujud manusia maupun dalam wujud binatang. Ingatan atau pengalaman-pengalaman tersebut yang diwariskan biasanya bersifat umum dan berulang secara terus-menerus tiap generasinya. Warisan tersebut merupakan memori yang yang lebih berpotensi untuk memikirkan sesuatu yang sifatnya tidak secara spesifik. Potensi yang membuat seseorang lebih peka terhadap sesuatu hal dan pembentukan kecenderungan tertentu dibutuhkan pengalaman dan proses belajar.

\section{a) Persona}

Persona adalah "topeng" yang dipakai seseorang sebagai respons atas tuntutan dari masyarakat di sekitarnya. Dengan kata lain, persona akan memainkan peran yang diinginkan orang-orang di sekitarnya. Persona bukanlah gambaran sebenarnya dari kepribadian dari seseorang karena ini sifatnya tentatif disebabkan dorongan orang lain dan lingkungan. Tujuan topeng ini untuk menciptakan kesan tertentu pada orangorang, ini merupakan lawan dari kepribadian privat yang berada di balik wajah sosial.

Seorang yang memiliki profesi sebagai dokter harus mampu menggunakan "topeng" sebagai dokter. Ia harus mampu merepresentasikan dirinya sebagai seorang dokter, yaitu figur yang mampu mengobati, mengetahui berbagai jenis penyakit, membuat resep obat, dan kepribadian melayani masyarakat. Ia akan berusaha semaksimal mungkin dalam menjalankan peran yang diembannya dan berusaha menyembunyikan jati diri aslinya. Hal tersebut terkait dengan tuntutan profesi dan lingkungannya.

Sederhananya, manusia yang menggunakan 'topeng' biasanya berkelakuan tidak sesuai dengan sifat pribadinya. Apa yang ia tampilkan hanyalah semata-mata untuk menyesuaikan dirinya dengan lingkungan hidup di sekitarnya.

\section{b) Anima dan Animus}

Anima merupakan karakteristik perempuan dalam diri seorang laki- laki, sedangkan animus merupakan karakteristik laki-laki dalam diri seorang perempuan.

Sisi feminin sudah melekat dalam diri perempuan atau wanita, sedangkan sisi maskulin melekat pada diri laki-laki 
atau pria. Jika dilihat dari ilmu fisiologis, laki-laki pada umumnya mengeluarkan hormon laki-laki, demikian juga dengan perempuan. Namun, jika berdasarakan pada ilmu psikologis, sifat-sifat maskulin dan feminin ada pada keduanya baik laki-laki maupun perempuan (Rokhmansyah \& Asmarani, 2018).

Sebagai contoh, dalam suatu keadaan yang mendesak yaitu ketika terjadi kebakaran. Seorang perempuan biasanya mampu melakukan pekerjaan di luar dari kebiasaannya. Ketika terjadi kecemasan akan sesuatu, sisi maskulin pada perempuan muncul dengan sendirinya. Hal itu baru diketahui setelah kecemasan itu sudah mereda. Seperti halnya dengan laki-laki, sisi femininnya akan muncul jika melihat sesuatu kejadian yang mengharukan. Tak sadar, air mata menetes. Hati menjadi luluh hingga meneteskan air mata. Terlihat bahwa, sisi feminin pada laki-laki telah muncul. Perubahan tersebut merupakan perubahan ilmiah dan termasuk kelebihan lain yang dimiliki manusia secara psikologis.

\section{c) Bayang-bayang (Shadow)}

Jung berpendapat bahwa arketipe ini merupakan naluri binatang yang diwarisi manusia dan mengalami perubahan dari bentuk-bentuk kehidupan manusia yang sangat rendah. Hal-hal yang muncul sebagai akibat dari arketipe ini berupa pikiran, perasaan, dan tindakan-tindakan yang tercela dan tidak dapat diterima oleh masyarakat.

Shadow merupakan sisi gelap ego manusia. sisi yang menunjukkan sifat jahat dalam diri seseorang. Semua hal yang jahat dalam diri manusia tersimpan di dalam shadow. Sebagai contoh, setiap orang yang ingin mencelakakan diri orang lain, bertindak meresahkan masyarakat, mencuri, merampok, dan sebagainya merupakan akibat yang dimunculkan oleh sisi shadow seseorang. Dorongan itu tidak dapat dikontrol karena muncul pada taraf ketidaksadaran, namun dapat juga muncul pada taraf kesadaran misalnya sesorang yang sedang marah.

\section{d) Diri (self)}

Self merupakan proses penyeimbangan antara taraf kesadaran dan taraf ketidaksadaran. Pada tarafini, seseorang mengalami keseimbangan dalam dirinya dan merasa utuh dan stabil. Seseorang dengan rela melepaskan sesuatu yang selama ini dicita-citakannya.

Berusaha mengikhlaskan dan merelakan karena sadar akan masa depan yang diperoleh. Contoh lain dari self adalah seseorang yang selalu mendekatkan diri dengan Tuhan-Nya. Hal itu dilakukan karena seseorang tersebut lebih nyaman dan aman dalam menikmati hidup ini jika terus percaya bahwa Tuhan bersama dirinya. Memberikan perlindungan disetiap langkahnya.

Tokoh-tokoh umumnya merupakan imajinasi atau khayalan pengarang yang berada dalam kondisi jiwa yang sehat maupun terganggu. Mempelajari psikologi berarti usaha untuk mengenal manusia. Mengenal berarti memahami, menguraikan, dan menggambarkan tingkah laku manusia beserta aspekaspek di dalamnya (Kusuma, 2012).

Novel Anak Rantau karya Ahmad Fuadi merupakan salah satu karya sastra Indonesia yang mengandung permainan kejiwaan tokoh-tokoh utamanya. Misalnya pada tokoh Hepi yang mengalami luapan kebecian, emosi, keputusasaan, kekecewaan yang disebabkan oleh ayah, kakek, bang Lenon, hingga orang-orang yang sudah dianggapnya sebagai saudara.

Alasan peneliti melakukan analisis padanovel Anak Rantau karya Ahmad Fuadi dari sisi psikologi sastra yang dalam hal ini menggunakan teori PsikoanalisisCarl Gustav Jung karena peneliti menemukan banyak konflik 
Riskal Ahmad: Ketidaksadaran Kolektif Tokoh dalam Novel Anak Rantau Karya Ahmad Fuadi (Kajian Psiokologi Analitis Carlgustav Jung)

batin yang dialami oleh para tokoh. Penelitian serupa pernah dilakukan oleh Yanni Husain Kusuma dengan judul penelitian "Ketidaksadaran dan Faktor yang Mempengaruhi Struktur Ketidaksadaran Tokoh (Aku) Novel Napas MayatKarya Bagus Dwi Hananto: Kajian Psikoanalitik Carl Gustav Jung". Hasil yang diperoleh adalah ketidaksadaran kolektif ditunjukkan oleh tokoh aku dengan adanya symptomdan komplek, mimpi, fantasi, khayalan, dan arketipe.

Terdapat beberapa perilaku psikologi yang tergambar dari setiap tokoh yang ada dalam novel Anak Rantau karya Ahmad Fuadi. Adanya pengalaman masa lalu, pergolakan batin, kondisi lingkungan yang dimunculkan menjadikan peneliti tertarik untuk melakukan penelitian lebih mendalam dari sisi psikologi tokohnya. Dengan demikian, peneliti merumuskan judul ketidaksadaran kolektif pada tokoh dalam novel Anak Rantaukarya Ahmad Fuadi melalui pendekatan PsikoanalisisCarl Gustav Jung.

\section{METODE}

Penelitian ini berupa studi pustaka yang disajikan secara deskriptif kualitatif. Sumber data diperoleh dari novel Anak Ranta karya Ahmad Fuadi yang dilakukan melalui analisis pada tokoh, dan hasilnya dideskripsikan secara kualitatif menggunakan teori Psikoanalisis Carl Gustav Jung. Tujuannya adalah mengetahui ketidaksadaran kolektif pada tokoh yang dapat dilihat melalui sikap, kejadianserta alur cerita yang terdapat dalam novel tersebut.

Penelitian ini merupakan penelitian kualitatif yang menjadikan peneliti sebagai instrumen itu sendiri. Instrumen manusia (human instrument) yang berarti peneliti merupakan instrumen kunci guna menangkap makna, interaksi nilai lokal dari nilai lokal yang berbeda karena hal ini tidak mungkin diungkapkan lewat kuesioner. Peneliti berfungsi untuk menentukan fokus penelitian, sumber data, pengumpulan data, dan sebagainya sampai ditemukannya hasil penelitian.

Sumber data primer yang digunakan dalam penelitian ini adalah teks yang berupa kata, frasa, dan kalimat dalam novel Anak Rantau karya Ahmad Fuadi. Novel yang diterbitkan pada bulan Juli 2017 oleh Falcon Publishing dan terdiri dari 370 halaman.

Data sekundernya adalah referensi dan jurnal hasil penelitian yang koheren dengan penelitian ini.

Selanjutnya, pengumpulan data yang merupakan langkah strategis dalam sebuah penelitian dilakukan. Tujuan utamanya adalah memperoleh data yang diinginkan. Teknik pengumpulan data dalam penelitian ini menggunakan teknik baca dan teknik catat.

Data yang diperoleh dalam penelitian ini dianalisis berdasarkan prinsip deskriptif kualitatif, dengan menggunakan pendekatan psikoanalitik Carl Gustav Jung dalam novel Anak Rantau karya Ahmad Fuadi.

Penelitian ini menggunakan teknik analisis isi yakni dilakukan dari data yang bersumber dari dokumen tertulis.

Langkah-langkah penelitian ini adalah: (1) menentukan sumber data penelitian, yaitu novel Anak Rantau karya Ahmad Fuadi; (2) membaca novel tersebut; (3) mengkalisifkasi kepribadian tokoh berdasarkan teori ketidaksadaran kolektif Carl Gustav Jung; (4) menganalisis data yang diperoleh; (5) menginterpretasi hasil analisis; dan (6) menyimpilkan hasil penelitian.

\section{HASIL DAN PEMBAHASAN}

Ketaksadaran kolektif merupakan gudang bekas-bekas ingatan laten yang diwariskan dari masa lampau leluhur sesorang. Masa lampau yang meliputi tidak hanya sejarah ras manusia sebagai 
suatu spesies tersendiri, tetapi juga leluhur pramanusiawi atau nenek moyangnya.

Struktur ketidaksadaran kolektif yang dibahas pada analisis ini adalah ketidaksadaran kolektif pada setiap tokoh yang terdapat dalam novel Anak Rantau karya Ahmad Fuadi. Struktur ketidaksadaran kolektif yang akan diungkap adalah bagian-bagian arketipe yang berupa persona (topeng), shadow (bayang-bayang), anima dan animus, dan self (diri). Berikut ini akan dipaparkan struktur ketidaksadaran kolektif tersebut.

\section{Persona}

\section{a. Datuk Marajo Labiah}

Datuk Marajo Labiah berusaha menyembunyikan senyum kemenangan di balik kumis tebalnya (Fuadi, 2017, hlm. 21).

Kutipan tersebut bahwa Datuk Marajo meski berkumis tebal, tetapi senyumnya tetap dapat terlihat. Entah karena senyum tersebut orang-orang kemudian menganggapnya ramah, padahal kenyataannya dia sering menghardik orang. Orang lain saja dihardik, terlebih anak dan istrinya.

Pernyataan mengenai hal tersebut lebih jelas diterangkan pada kutipan berikut:

Karena itu dia pasang lagi topeng muka marah dan menghardik ketidakpatuhan Martiaz seperti yang dulu biasa dia lakukan (Fuadi, 2017, hlm. 124).

Kutipan tersebut menjelaskan kepribadian yang sebenarnya dimiliki oleh Datuk Marajo telah tersembunyi dan menampilkan bagian luar atau topeng untuk ditunjukkan pada anak, istri, dan masyarakat.

\section{b. Martiaz}

Jakarta bisa merusak kau," katanya dengan suara kaku, walau dalam hati dia tahu bukan Jakarta yang salah, melainkan dia yang tidak berdaya melindungi anaknya(Fuadi, 2017, hlm. 51).

Kutipan tersebut menampilkan peranan persona dari seorang ayah untuk ia tampilkan pada anaknya. Persona ini ia tampilakn sebagai bukti cinta karena ia khawatir pada anaknya sehingga mengatakan sesuatu yang belum tentu jelas kebenarannya? Kutipannya sepertinya kurang tepat untuk menampilkan kegagalan orang tua mendidik anak

Orang tua seringkali memproyeksikan peranan persona pada anak-anaknya dan berupaya memaksakan standar-standar perilaku yang sesuai dengan yang diharapkannya. Kutipan di atas juga menerangkan sikap seorang ayah yang tidak lahir dari keinginannya sendiri melainkan menyerukan kebohongan belaka untuk membuat personanya atau tampilan luarnya dapat dipercaya dan lebih alamiah.

Kebohongan atau topeng yang ditampilkan dari seorang ayah tersebut terbukti dari keterangan kutipan berikut:

Ada penyesalan menyusup ke dalam hatinya ketika mendengar suaranya sendiri. Satu hal yang Hepi tidak tahu, begitu bus bertolak, mata ayahnya juga berlinang menatap anaknya dari kejauhan (Fuadi, 2017, hlm. 54-55).

Persona adalah topeng atau bagian luar yang ditunjukkan seorang ayah di depan anaknya dengan tujuan memberikan satu kesan yang dapat diterima oleh anak tersebut.

\section{c. Lenon}

Tampak nyata Lenon telah insyaf dan kembali ke jalan yang benar. Banyak saksi yang melihat, setiap ziarah ke pusara ibunya, dia selalu ikut salat berjamaah ke surau dan bercakap-cakap ramah dengan warga (Fuadi, 2017, hlm. 73). 
Riskal Ahmad: Ketidaksadaran Kolektif Tokoh dalam Novel Anak Rantau Karya Ahmad Fuadi (Kajian Psiokologi Analitis Carlgustav Jung)

Warung kecil punya ibunya yang terletak di sebelah pos ronda telah diubahnya menjadi warung pernik dan aksesori,hasil karya dia dengan para preman, dan sebagian lagi dia beli dari Tanah Abang.Dia menjajakan saputangan berbagai rupadan ukuran, ada rol rambut, peniti, pita aneka wara, serta barang kecil remeh-temeh lainnya. (Fuadi, 2017, hlm. 74).

Lenon masih memelihara rambut terurai sebahu dan bertato di sanasini, tapi kini dia punya ciri baru:membawa tasbih kecil ke mana-mana. Kalau hari Jumat, dia sudah berjalan ke masjid sebelum azan dan duduk di saf pertama. Bahkan, kelompok preman yang dibawahi Lenon ikut pula dengan senang hati untuk membela keamanan kampungnya. "premanpreman macam kami ini selalu cinta kampung," kata Lenon(Fuadi, 2017, hlm. 202).

Beberapa kutipan di atas menampilkan perilaku seseorang yang sedang memakai topeng yang membuatnya bisa menampilkan peranan khusus, yakni karakter yang baik dan alim. Peranan persona tersebut ia pakai untuk membuat ia bisa bergaul dan bisa diterima dimasyarakat umum.

Citranya sebagai preman di Jakarta membuatnya kembali ke kampung kelahirannya dengan memerankan peranan sebagai seseorang yang telah insyaf dan kembali ke jalan Allah. Bang Lenon berusaha dengan keras menampilkan karakter yang bukan merupakan miliknya seperti rajin salat berjamaah di surau, membawa tasbih, dan ikut menjaga keamanan kampung.

Pernyataan tersebut dapat dibuktikan dari beberapa kutipa berikut:

Mata Lenon menajam ketika melihat Hepi. Hepi tidak habis pikir. Apakah ini nyata atau cuma halusinasi? Bagaimana ceritanya Lenon ada di surau tua ini juga? (Fuadi, 2017, hlm. 321).

Hepi bertanya-tanya dalam kepalanya. Meracuni kampung halamannya dengan narkoba? Bukankah kini dia sudah rajin salat ke surau dan kadang ikut menyimak ceramah? Bukankah dia orang yang dipercaya Ayah dulu?Bukankah dia ikut ronda dan menangkap maling? (Fuadi, 2017, hlm. 321).

"Tapi, Bang Lenon kan sudah insyaf. Apa sering salat di surau itu sandiwara saja?" Tanya Hepi. Lenon tertawa lepas, diikuti ketawa kecil kawan-kawannya. (Fuadi, 2017, hlm. 323).

Beberapa kutipan di atas menjelaskan bahwa tokoh Lenon hanya memainkan peran di luar dari karakter utamanya sebagai penjahat. Ia tidak pernah benar-benar bertaubat. Sifatnya yang alim dan pekerjaannya sebagai pengrajin hanya ia gunakan sebagai topeng untuk melancarkan perjalanannya menyebarkan narkoba.

Pernyataan tersebut dapat dibuktikan dari kutipan berikut:

"Kau ini benar otak bodoh atau purapura bodoh? Memangnya, semua pesanan belanja orang itu hanya kerajinan kayu, sarung, vasmina, sapu tangan, dan lainnya? Di dalam sebagian pesanan ini ada paket narkoba"

"Jadi, warung dan bengkel kerajinan itu haya bohong-bohongan belaka?" (Fuadi, 2017, hlm. 326).

Kutipan tersebut menerangkan bahwa usaha yang ia bangun hanya merupakan media untuk dia bisa membagikan narkoba pada konsumennya tanpa diketahui oleh masyarakat umum. 


\section{c. Nopen}

Selain anak-anak, banyak orang lain yang ikut mengaji Yasin. Hepi melihat bahkan ada Bang Leon, Bang Nopen, para kawan diskusinya di lapau,dan guru-guru(Fuadi, 2017, hlm. 109).

Kutipan tersebut menjelaskan tentang kepribadian tokoh Nopen sebagai seseorang yang taat dalam agamanya. Ia bahkan menjadi pengurus surau, tetapi sifat tersebut diperankan untuk tujuan tertentu yakni mendapat perhatian dari masyarakat sebagai orang yang baik. Personanya ia butuhkan untuk bertahan hidup karena karakter sebenarnya dari seorang Nopen adalah pencuri di kampung.

Pernyataan tersebut dikuatkan dari beberapa kutipan berikut.

Dia kaget melihat muka orang yag paling ujungdan paling jauh darinya. Hepi perlu berdiri dan mendekat untuk memastikan dia tidak salah lihat. "Bang Nopen? Kenapa di sini?"

Nopen membuang muka malu. Kakek yang baru saja sadar melotot dengan garang. "Nopen, benar ini? Kurang ajar betul wa'ang kini, ya. Wa'ang sudah gila? Kenapa?" (Fuadi, 2017, hlm. 292).

Saldi menjelaskan bahwa tiga orang pertama adalah pencuri dan Nopen dengan tiga kawan lainnya adalah komplotan mereka yang berjaga di jalan untuk memberi tahu kalau ada ronda dan lainnya. (Fuadi, 2017, hlm. 293).

"Nopen, wa'ang benar-benar anak tak tahu diuntung. Percuma selama ini wa'ang aku percaya mengurus surau dan keramba. Setan apa yang merasuki kau?" (Fuadi, 2017, hlm. 294).

Beberapa kutipan di atas menjelaskan karakter asli dari tokoh
Nopen sebagai pencuri yang tidak dapat dipercaya warga karena ia telah berpurapura menjadi orang yang baik, taat beragama, bahkan menjadi penjaga surau.

\section{d. Datuk Mudo}

"Yang meninggal itu? Masak Datuk Mudo yang beradat itu pemakai juga?" Hepi ingat sekali pelanggan favoritnya di lapau itu (Fuadi, 2017, hlm. 325).

"Ah, sudah terlanjur saya sebut. Datuk Mudo adalah pelanggan lama yang menyenangkan. Ngobat untuk bersenang-senang saja dan untuk tambahan stamina bekerja (325).

Setelah kaget dengan Bang Nopen, kini dia tercekat menyadari bahwa almarhum Datuk Mudo, yang dia ikut bacakan Yasin di rumahnya, ternyata adalah pemakai narkoba. Padahal, keluargnya tampak alim dan lemah lembut (325).

Beberapa kutipan di atas menerangkan karakter yg sebenarnya dimiliki oleh Datuk Mudo. Di depan masyarakat umum, ia memerankan peran yang yang alim, tetapi yang sebenarnya dia adalah seorang pemakai narkoba.

\section{Anima}

\section{a. Martiaz}

'Sesekali sarapan bareng dong, Yah. Ada nasi goreng padang petai nih.' Dora, anaknya berteriak sambil mengacau-ngacau isi kuali di depannya."Asal rasanya tidak kalah saja dengan buatan Ayah, ya". Martiaz menjawab dengan tersenyum sambil bergegas meraih handuk(Fuadi, 2017, hlm. 5).

Kutipan tersebut menjelaskan peranan arketipe anima dalam diri tokoh Martiaz yakni sisi feminin yang ada dalam diri seorang pria. Arketipe anima menurut Jung memiliki nilai bertahan hidup yang kuat. Hal inilah yang 
Riskal Ahmad: Ketidaksadaran Kolektif Tokoh dalam Novel Anak Rantau Karya Ahmad Fuadi (Kajian Psiokologi Analitis Carlgustav Jung)

ditunjukkan pada tokoh Martiaz. Seorang ayah yag menunjukkan sisi femininnya untuk menggantikan peranan ibu dengan mengambil alih pekerjaan dapur yang biasanya dikerjakan oleh seorang wanita.

Dia teringat istrinya. Hepi telah dia manjakan lebih daripada kakaknya, karena dia tahu anaknya ini tidak pernah dapat kasih sayang seorang ibu. Dia kadang bingung kapan harus lunak dan kapan harus keras kepada hepi. Kalau sudah suntuk begini, biasa Martiaz bergegas menjenguk pusara istrinya di bawah pohon kamboja berbunga merah jambu, di Karet Bivak. Sambil menaruh melati putih, dia bacakan Al-Fatihah dan mengadukan perasaan membesarkan Hepi dan Dora di hadapan nisan istrinya (Fuadi, 2017, hlm.51-52).

Kutipan tersebut menjelaskan peranan arketipe anima yang terjadi dalam diri seorang ayah. Arketipe ini menunjukkan sifat lemah dan sifat mudah dipengaruhi pada ketaksadaran. Itulah mengapa seorang ayahyang seharusnya tampak paling jantan dan bertindak tegas seringkali lemah dan penurut di dalam hatinya.

\section{b. Lenon}

Mana ada anak bujang yang mau belanja keperluan dapur dan warung ke pasar di kampung? Belanja tetek bengek rumah tangga biasanya dianggap kerja perempuan. Tapi itu yang sering dilakukan Lenon untuk menggantikan ibunya yang sering sakit dan pening kalau melihat orang ramai (Fuadi, 2017, hlm. 73).

Kutipan tersebut menjelaskan peranan arketipe anima dalam diri tokoh Lenon yakni sisi feminin yang ada dalam diri seorang pria. Karakter feminin tokoh Lenon berkembang dari situasi yang dia hadapi yakni ketidakmampuan ibunya untuk melakukan pekerjaannya. Hal itulah yang menekan ketaksadaran
Lenon untuk mengerjakan pekerjaan yang seharusnya menjadi pekerjaan wanita.

\section{Animus}

\section{a. Nenek Salisah}

Dengan pintu kamar masih renggang terbuka, Hepi bisa mendengar semuanya dengan jelas. Mulut neneknya terdengar seperti mitraliur, melancarkan serangan "trat-tat-tat-tat" tidak berjeda(Fuadi, 2017, hlm. 82).

Hepi terkesima melihat neneknya yang selama ini lemah lembut tiba-tiba bagai seekor induk anak ayam beranak kecil yang siap melibas dan mematuk siapa saja(Fuadi, 2017, hlm. 82).

Beberapa kutipan di atas menunjukkan peranan arketipe animus pada tokoh Nenek Salisah, yakni sisi maskulin pada seorang wanita. Jika seorang wanita mengalami keengganan dan merasa dalam situasi yang tidak adil, maka sisi maskulin dari perilaku lahiriah seorang pria akan mampu ditunjukkan oleh seorang wanita. Sisi inilah yang ditunjukkan oleh Nenek Salisah untuk membela cucunya.

\section{Bayang(shadow)}

\section{a. Lenon}

Lenon naik tahta bukan hanya dengan cara mengalahkan preman yang berkuasa. Tapi, dia menamatkan riwayat Rambo, preman besar pemabuk dan pemadat yang sudah meresahkan para pedagang. Juga merepotkan polisi. Setelah duel, Lenon menyeret badan preman ini sepanjang los pasar menuju pos polisi. Setelah beberapa tahun berkuasa, dia terlibat perkelahian satu lawan satu dengan penantangnya yang ingin menggulingkan kekuasaannya. Setelah pertarungan sengit, lawannya kembali mampus di tangannya (Fuadi, 2017, hlm. 72). 
Bayang mengandung sifat hewani mendasar manusia yang apabila seseorang tersebut mengalami depresi, maka akan menjadikan manusia tersebut seperti binatang buas. Hal seperti inilah yang dialami oleh tokoh Lenon. Kutipan di atas menerangkan dirinya sebagai seseorang yang mampu membunuh preman terkuat di kota itu sedangkan dahulunya ia adalah anak yang patuh pada orang tua. Kecintaannya pada orang tuanyalah yang menjadikan ia seperti binatang buas. Ia merasa sangat depresi saat ayahnya meninggalkan ibunya yang sedang sakit untuk menikah lagi.

Pernyataan tersebut dikuatkan dari kutipan berikut:

Mana ada anak bujang yang mau belanja keperluan dapur dan warung ke pasar di kampung? Belanja tetek bengek rumah tangga biasanya dianggap kerja perempuan. Tapi itu yang sering dilakukan Lenon untuk menggantikan ibunya yang sering sakit dan pening kalau melihat orang ramai. Sampai suatu hari dia berselisih sengit dengan ayahnya, saat ayahnya kawin lagi. Anehnya ibunya tidak menolak dimadu, bahkan pasrah saja ketika akhirnya diceraikan ayahnya. Lenon kecewa kepada kedua orangtuanya dan merantau ke Jakarta (Fuadi, 2017, hlm. 73).

\section{b. Jenggo}

Attar berbisik ke Hepi dengan bibir bergetar, "Dia mantan narapidana yang membunuh dengan dingin sebuah keluarga dan anak-anak kecil di kampung sebelah" (Fuadi, 2017, hlm. 329).

Jenggo yang tambun dibantu dua kawannya yang kekar, satu berambut cepak dan satu berkumis landak, dengan enteng mencokok Hepi, Attar, dan Zen kemudian mengempaskan mereka ke sudut surau tua itu. Dinding kayu lapuk itu berderak dan bergoyang- goyang. Lalu Jenggo dengan cekatan membuat buhul dari tambang kasar seibu jari dan menggantungkannya di palang kayu. Dalam beberapa kedip mata, satu kalung tali telah menggantung di depan wajah Hepi. Dua kalung lagi disiapkan Jenggo untuk Attar dan Zen(Fuadi, 2017, hlm. 331).

Dia lalu menegakkan Hepi di atas sebuah kaleng besar bekas cat dengan hati-hati mengalungkan tali itu ke lehernya, bagai mempersembahkan medali. Sebuah tali yang kasar menyayat kulitnya yang pedih (Fuadi, 2017, hlm. 332).

Bayang merupakan insting binatang yang diwarisi manusia dalam evolusinya dari bentuk-bentuk kehidupan yang lebih rendah. Arketipe ini mengakibatkan munculnya tindakan kekerasan apabila seseorang menghadapi situasi yang sulit dan merasa takut ketahuan atas tindakan tercela yang sedang ia lakukan.

Hal inilah yang dirasakan oleh tokoh Jenggo. Beberapa kutipan di atas menjelaskan tindakan kekerasan yang dilakukan tokoh Jenggo untuk menutupi kesalahannya. Ia mempersiapkan dirinya untuk membunuh tiga anak tanpa merasa takut, hal itu disebabkan oleh desakan kekuatan atas egonya yang membuat dirinya seperti binatang buas.

\section{Diri (self)}

\section{a. Datuk Marajo Labiah}

Datuk pikir-pikir, mungkin pula Lenon dan para preman ini seperti dia, sedang menebus dosa dari kejahatan masa lalu. Dalam hati yang paling dalam, walau berat untuk megakui, dia merasa tidak lebih baik daripada mereka(Fuadi, 2017, hlm. 85).

Sejak pensiun dan banyak waktu berdiam diri sendiri di rumah, Datuk mulai takut mati. Pernah dia duduk sendiri, ditemani kalkulatordan menulis di sebuah kertas, membuat neraca dosa 
Riskal Ahmad: Ketidaksadaran Kolektif Tokoh dalam Novel Anak Rantau Karya Ahmad Fuadi (Kajian Psiokologi Analitis Carlgustav Jung)

dan pahalanya. Ternyata menurut hitungannya sendiri, dosanya sekitar tiga ribu persen lebih banyak daripada pahalanya(Fuadi, 2017, hlm. 120-121).

Dia mulai mencari cara mendekati Tuhan. Malam-malam selesai tahajud, dia usap matanya yang basah. Dia pikirpikir, mungkin anaknya Martiaz, darah dagingnya sendiri, telah memakan rezeki haram yang dia bawa pulang. Akibatnya dia menjadi pembangkang, jadi preman, dan jadi seperti sekarang(Fuadi, 2017, hlm. 121).

Diri adalah pusat dari kepribadian manusia. Arketipe diri akan selalu berkembang dan terus berjuang untuk menyeimbangkan kepribadian seseorang antara sadar dan ketaksadaran yang dialami orang tersebut. Saat seseorang mampu untuk berdamai dan merasa bahagia dengan dirinya dan dengan dunianya,dapat diyakini bahwa arketipe diri menjalankan kinerjanya dengan efektif.

\section{DAFTAR PUSTAKA}

Fuadi, A. (2017). Anak Rantau. In E. Sumbodo (Ed.), Falcon Publishing(Pertama). PT Falcon. https://doi.org/10.1016/j.jpainsymm an.2017.04.009

Hall, C. S., \& Nordby, V. J. (2018). Psikologi Jung Sebuah Bacaan Awal (T. Setiadi (ed.); Pertama). Basabasi.

https://doi.org/10.1017/CBO978110 7415324.004

Ismail, F. (1999). Pemikiran Carl Gustav Jung Tentang Teori Kepribadian (Implikasinya Terhadap Interaksi Sosial). https://docplayer.info/38275328-

Pemikiran-carl-gustav-jungtentang-teori-kepribadianimplikasinya-terhadap-interaksisosial-feiby-ismail-1-abstrak.html

Kusuma, Y. H. (2012). Ketidaksadaran dan faktor yang mempengaruhi struktur ketidaksadaran tokoh utama (aku) novel Napas Mayat karya Bagus Dwi Hananto: kajian psikologi analitis Carl Gustav Jung (Vol. 01). Universitas Negeri Surabaya.

Minderop, A. (2010). Psikologi Sastra: Karya Sastra, Metode, Teori, dan Contoh Kasus. Yayasan Pustaka Obor Indonesia.

Mutmainna. (2016). Kesadaran Dan Ketidaksadaran Tokoh Dalam Novel Tarian Dua Wajah Karya S. Prasetyo Utomo Kajian Psikologi Analitis Carl Gustav Jung. Universitas Negeri Makassar.

Qudwah, A. (2016). Ketidaksadaran Personal, Ketidaksadaran Kolektif, dan Arketipe Sebagai Tingkatan Psike Pada Tokoh Utama Dalam Roman Et Si C'etait Vrai Karya Marc Levy: Kajian Psikologi Analitis Carl Gustav Jung[Universitas Negeri Semarang]. https://lib.unnes.ac.id/29432/1/2311 412004.PDF

Rokhmansyah, A., \& Asmarani, R. (2018). Struktur Ketaksadaran Kolektif Tokoh Utama Dalam Novel The Sweet Sins Karya Rangga Wirianto Putra. Aksara, 30(2), 221. https://doi.org/10.29255/aksara.v30i 2.321.215-229

Sembiring, R. H., Herlina, \& Attas, S. G. (2018). Kepribadian Tokoh Utama dalam Novel Negeri Para Bedebah Karya Tere Liye Kajian Psikoanalisis Carl Gustav Jung Renni. Transformatika: Jurnal Bahasa, Sastra, Dan Pengajarannya, 2(12), 157-171. https://doi.org/10.31002/transforma tika.v

Septiarini, T., \& Sembiring, R. H. (2017). Kepribadian Tokoh Dalam Novel Mencari Perempuan Yang Hilang (Kajian Psikoanalisis Carl 
Gustav Jung). LiNGUA, 12(2), 7989.

Shiva, N. (2012). Kesadaran dan Ketidaksadaran Tokoh Ara dalam Cerpen "Ingatan Ara" Karya Dewi Ria Utari: Analisis Psikologi Sastra (Vol. 53, Issue 9). https://doi.org/10.1017/CBO978110 7415324.004

Supratiknya, A. (1993). Teori - Teori Psikodinamika (Klinis) (A. Supratiknya (ed.)). Kanisius. https://docplayer.info/38275328-

Pemikiran-carl-gustav-jungtentang-teori-kepribadianimplikasinya-terhadap-interaksisosial-feiby-ismail-1-abstrak.html

Wiyatmi. (2011). Psikologi Sastra: Teori dan Aplikasinya. Kanwa Publisher. 